\title{
Tatalaksana Medikamentosa pada Penyakit Saluran Cerna
}

\author{
Handre Putra, Yusri Dianne Jurnalis, Yorva Sayoeti
}

\begin{abstract}
Abstrak
Pengeluaran isi lambung menuju esophagus (gastroesofageal reflux/GER) merupakan proses fisiologis normal pada bayi sehat, anak dan remaja. Episode singkat, tidak menimbulkan gejala, kerusakan esophagus atau komplikasi lainnya. Gastroesofageal reflux disease (GERD) adalah bila episode tersebut disertai gejala dan kompikasi. Beberapa pilihan terapi bertujuan mengontrol gejala dan mencegah komplikasi pada anak dengan GERD tergantung usia, tipe dan derajat beratnya gejala serta respon terapi. Abdominal pain adalah sindrom episodik pada masa kanak-kanak ditandai beberapa episode nyeri perut dan gejala vasomotor, mual dan muntah. Konstipasi fungsional sering terjadi pada anak usia prasekolah yang harus ditatalaksana secara adekuat untuk mencegah semakin beratnya konstipasi dan menimbulkan beban psikososial. Functional abdominal pain disorders (FAPDs) merupakan penyebab nyeri abdomen kronik pada anak dan remaja yang melibatkan interaksi antara faktor regulasi dalam sistem saraf enterik dan pusat yang bersifat menetap sehingga memiliki efek buruk pada gejala psikologik. Perdarahan saluran cerna disebut sebagai perdarahan saluran cerna atas bila berasal dari bagian proksimal ligamentum Treitz, dan perdarahan saluran cerna bawah bila berada di bagian distalnya. Kelima penyakit saluran cerna ini memiliki insiden yang cukup tinggi pada anak, dan akan dibahas mengenai tatalaksana medikamentosa terkini pada kelima penyakit tersebut.
\end{abstract}

Kata kunci: GERD, abdominal migraine, konstipasi, FAPDs dan perdarahan saluran cerna

\begin{abstract}
Gastroesofageal reflux (GER) is a normal physiological process in healthy infants, children and adolescents. Most episodes are brief and without symptoms or other complications. Gastroesophageal reflux disease (GERD) is when the episode is accompanied by symptoms and complications. Several treatment options are available in children with GERD depending on age, type and severity of symptoms and therapeutic response. Abdominal pain is an episodic syndrome in childhood characterized by several episodes of abdominal pain and vasomotor symptoms, nausea and vomiting. Functional constipation is common in preschoolers who need to be adequately managed to prevent the onset of constipation and psychosocial burdens. Functional abdominal pain disorders (FAPDs) are the cause of chronic abdominal pain in children and adolescents involving the interaction between regulatory factors in the enteric and central nervous systems that are sedentary and therefore have adverse effects on psychological symptoms. Gastrointestinal haemorrhage is referred as upper gastrointestinal bleeding when it comes from the proximal portion of the Treitz ligament, and lower gastrointestinal haemorrhage when in the distal region. These five gastrointestinal diseases have a high incidence in children, and will be discussed about the latest medical management of the five diseases.
\end{abstract}

Keywords: GERD, abdominal migraine, constipation, FAPDs and gastrointestinal bleeding

Affiliasi penulis: Bagian IImu Kesehatan Anak Fakultas Kedokteran Universitas Andalas/RSUP Dr. M. Djamil

Korespondensi: yusridianne12@gmail.com Telp:081363931569

\section{PENDAHULUAN}

Pengeluaran isi lambung menuju esophagus (gastroesofageal reflux / GER) merupakan proses fisiologis normal pada bayi sehat, anak dan remaja. Kebanyakan episode singkat dan tidak menimbulkan gejala, kerusakan esophagus atau komplikasi lainnya. Gastroesofageal reflux disease (GERD) adalah bila episode tersebut disertai gejala dan kompikasi. Beberapa pilihan terapi tersedia untuk mengontrol gejala dan mencegah komplikasi pada anak dengan 
GERD. Pilihannya tergantung dengan usia, tipe dan derajat beratnya gejala dan respon terhadap terapi. ${ }^{1}$

Abdominal migrain merupakan sindrom episodik yang ditemukan pada masa kanak-kanak yang ditandai oleh beberapa episode nyeri perut dan gejala vasomotor, mual dan muntah. Penyakit ini kurang begitu dipahami karena kurangnya kontak komunitas medis terhadap penyakit ini. ${ }^{2}$

Konstipasi fungsional bertanggung jawab terhadap 95\% kasus konstipasi pada anak sehat usia 1 tahun keatas, dan secara khusus sering terjadi pada anak usia prasekolah. Intervensi yang terlambat atau inadekuat akan menyebabkan kebiasaan menahan defekasi yang akan memperberat konstipasi dan menyebabkan konsekuensi psikososial. ${ }^{3}$

Functional abdominal pain disorders (FAPDs) merupakan penyebab nyeri abdomen kronik pada anak dan remaja. FAPD melibatkan interaksi antara faktorfaktor regulasi dalam sistem saraf enterik dan pusat. FAPD mungkin berhubungan dengan hiperalgesia viseral, ambang batas berkurang untuk nyeri, rujukan nyeri abnormal setelah distensi rektum atau gangguan respons relaksasi lambung terhadap makanan. Selain itu, pengalaman nyeri yang menetap dapat memiliki efek buruk pada gejala psikologik. ${ }^{4}$

Perdarahan saluran cerna dapat bersifat tersamar atau nyata. Perdarahan tersamar memberikan gejala lemah, anemia defisiensi besi, dan teridentifikasi saat pemeriksaan feses pada anak. Perdarahan nyata dapat bermanifestasi sebagai muntah darah atau berwarna kehitaman seperti kopi (hematemesis), atau melalui rectum (melena atau hematoskezia). Perdarahan disebut perdarahan saluran cerna atas bila berasal dari bagian proksimal ligamentum Treitz, dan perdarahan saluran cerna bawah bila berada di bagian distalnya. $^{5}$

\section{ISI}

\section{Gastroesophageal Reflux Disease (GERD)}

Gastroesofageal reflux dan regurgitasi cukup sering ditemukan pada bayi dan biasanya membaik sendiri saat bayi mencapai usia 1 tahun. Istilah GERD digunakan apabila refluks sudah menimbulkan gejala patologi seperti esofagitis, gangguan nutrisi atau komplikasi pernafasan. $^{1}$

\section{Bayi dan anak muda ${ }^{6}$}

a. Modifikasi gaya hidup

Modifikasi gaya hidup yang dapat dilakukan pada bayi dengan GERD antara lain

- Paparan terhadap asap rokok

Nikotin dapat menurunkan tekanan sfingter esofagus bawah, tetapi apakah asap rokok dapat mencetus terjadinya refluks pada bayi masih belum terbukti.

- Jumlah makanan

Refluks sederhana dapat dicetus oleh peregangan lambung sehingga dengan memberikan makanan dalam jumlah sedikit dapat mengurangi frekuensi dan kuantitas refluks. Hal ini terutama dapat dilakukan pada bayi yang mendapat susu formula, dengan mempromosikan pemberian makanan dalam porsi kecil tapi sering, dan/atau dengan formula yang lebih kental.

- Diet bebas susu

Intoleransi terhadap protein (khususnya alergi susu sapi) dapat memberikan gejala yang mirip dengan GERD.

- ASI vs susu formula

ASI dapat bersifat sebagai agen protektif, terbukti pada bayi dengan GERD yang mendapatkan ASI mengalami paparan asam lambung yang lebih sedikit dibandingkan dengan bayi yang mendapatkan susu formula. Mungkin disebabkan karena pola pengosongan lambung yang berbeda dan intoleransi terhadap protein susu.

- Makanan yang dikentalkan

Makanan yang dikentalkan terbukti dapat memperbaiki gejala dan frekuensi refluks. Dalam suatu studi metaanalisis memperlihatkan berkurangnya frekuensi muntah. ASI atau susu formula dapat dikentalkan dengan memberikan sereal oat hingga 1 sendok makan per 1 ons susu.

- Terapi posisi

Memposisikan bayi dalam posisi tegak lurus selama 20-30 menit setelah makan dapat mengurangi regurgitasi. Posisi tidur menelungkup terbukti dapat mengurangi refluks 
tetapi meningkatkatkan risiko terjadinya sudden infant death syndrome (SIDS).

b. Farmakoterapi

Obat untuk menekan asam lambung mempunyai sedikit peranan pada bayi karena tidak cukup valuable untuk menatalaksana bayi dibawah usia 1 tahun dengan GER tanpa komplikasi. Bila farmakoterapi menjadi pilihan terapi maka penggunaan PPI lebih direkomendasikan dibandingkan dengan antagonis reseptor histamine tipe 2 (H2RA). Bayi dan anak muda memetabolisme PPI lebih cepat dibandingkan dewasa sehingga membutuhkan dosis yang lebih tinggi, dan diberikan 30 menit sebelum makan.

\section{Anak besar dan Remaja ${ }^{7,8}$}

Tatalaksana GERD disini tidak jauh berbeda dengan dewasa yaitu terdiri dari modifikasi gaya hidup disamping pengobatan farmakoterapi.

a. Modifikasi gaya hidup

Modifikasi gaya hidup diantaranya menurunkan berat badan pada pasien overweight/obesitas dan mengurangi kebiasaan merokok dan konsumsi alkohol. Penggunaan kafein, alkohol dan makanan asam/berbumbu harus dikurangi karena sangat potensial dalam menyebabkan gejala GERD. Sebagai tambahan makan dengan porsi kecil tetapi sering, meninggikan kepala saat tidur, menghindari makan dalam jumlah besar menjelang tidur merupakan hal sederhana yang mudah diaplikasikan pada penderita GERD.

b. Farmakoterapi

Obat-obatan yang digunakan untuk menatalaksana GERD dapat dikelompokkan menjadi beberapa kategori, yaitu:

- $\quad$ Proton pump inhibitors (PPI)

PPI menghambat sekresi asam dengan berikatan secara ireversibel dan menghambat pompa hydrogen potassium ATPase yang terletak di permukaan luminal membran sel parietal. Golongan obat PPI antara lain omeprazole, lansoprazol, rabeprazole, pantoprazole, esomeprazole dan dexlansoprazole. Omeprazole, esomeprazole, lansoprazole dan dexlansoprazole merupakan PPI yang paling banyak diteliti penggunaannya pada anak. Dosis omeprazole efektif untuk anak 0.3-3.5 mg/kg/hr (maksimal $80 \mathrm{mg} / \mathrm{hr}$ ), lansoprazole 0.73-1.6 mg/kg/hr (maksimal 30 $\mathrm{mg} / \mathrm{hr}$ ). Dimulai dengan dosis tunggal dan dapat ditingkatkan menjadi dua kali sehari. Berikan 2 sampai 4 minggu untuk rasa panas pada perut derajat sedang sampai berat, 4 sampai 8 minggu bila terdapat bukti esofagitis. Bila esofagitis bersifat erosif (berat) pemberian PPI dapat dilanjutkan selama 3 sampai 6 bulan diikuti oleh pemeriksaan endoskopi untuk memantau penyembuhan. Penggunaan PPI jangka panjang dapat meningkatkan risiko infeksi usus terutama Clostridium difficile, kelainan metabolik dan nutrisi. Oleh karena itu pasien dengan PPI harus dipantau untuk mendeteksi kelainan tersebut. Pengobatan dapat dihentikan setelah 6 bulan dengan menurunkan dosis bertahap dan dapat diberikan secara periodik setelahnya tergantung gejala.

- $\quad$ Antagonis reseptor histamin tipe 2 (H2RA) Antagonis reseptor histamin tipe 2 (H2RA) digunakan pada pasien dengan GERD sedang atau gejala intermiten. H2RA mempunyai efek moderat terhadap GER, karena onset kerjanya yang cepat sangat cocok untuk meredakan gejala. Tetapi obat ini tidak seefektif PPI terutama pada penderita kronik. H2RA menghambat sekresi asam dengan menghambat reseptor histamine $\mathrm{H} 2$ pada sel parietal. Simetidin, ranitidine, famotidine dan nizatidin merupakan obat golongan H2RA. ${ }^{8}$ Puncak onset kerja H2RA adalah 2.5 jam dengan lama kerja 4 sampai 10 jam sehingga tidak cocok untuk penggunaan jangka panjang. Penggunaan H2RA jangka panjang meningkatkan risiko infeksi usus terutama oleh C. difficile dan community-acquired pneumonia.

- Antasid

Antasid sesuai untuk mengatasi keluhan rasa nyeri ulu hati jangka pendek pada anak besar, remaja atau dewasa dengan gejala jarang (kurang dari 1 kali seminggu). Antasid dapat mengatasi rasa nyeri pada ulu hati dalam waktu 5 menit tetapi dengan masa kerja yang pendek 
yaitu 30-60 menit. Antasid bekerja dengan menetralisir $\mathrm{pH}$ lambung sehingga mengurangi paparan mukosa esofagus terhadap asam lambung selama episode refluks. Antasid mengandung kombinasi magnesium, aluminium hidroksida dan kalsium karbonat. Penggunaan antasid pada bayi dapat menyebabkan meningkatnya kadar aluminium plasma sehingga menyebabkan osteopenia, anemia mikrositik, dan neurotoksisitas sehingga penggunaannya hanya terbatas pada anak besar dan remaja.

\section{- Surface agents}

Surface agents bekerja dengan menciptakan pertahanan yang menghalangi cedera pada mukosa yang diakibatkan oleh asam lambung. Hanya dua yang telah dievaluasi sebagai terapi pada pasien GERD yaitu sodium alginate dan sukralfat. Sukralfat (aluminium sucrose sulfat) memberikan kesembuhan mukosa dan melindungi kerusakan selanjutnya akibat asam lambung

- Prokinetik

Peran prokinetik dalam tatalaksana GERD masih terbatas karena alasan keamanan dan mamfaat, seperti metoklopramid, cisapride atau domperidon dan eritromisin. Baclofen merupakan antagonis reseptor gamma-aminobutyric acid $B$ (GABA-B) yang menghambat relaksasi transien dari sfingter bawah esophagus. Beberapa penelitian menunjukkan baclofen akan mengurangi gejala refluks, mengurangi frekuensi relaksasi sfingter esophagus dan paparan asam lambung terhadap esophagus, serta mempercepat pengosongan lambung. Efek samping baclofen seperti dyspepsia, mengantuk, dan mengurangi ambang kejang sehingga penggunaan baclofen jarang pada anak kecuali dengan adanya penyakit dasar neurologis.

\section{Abdominal Migraine}

Abdominal migrain merupakan kelainan fungsional dalam arti yang luas (suatu kelainan tanpa diketahui abnormalitas struktural atau biokimianya). Nyeri datang bersama gejala migrain seperti gangguan sensori (fotofobia, fonofobia), anoreksia, mual, muntah dan pucat. Pasien sehat dan bebas gejala antara episode serangan dengan pemeriksaan fisik normal dan indeks massa tubuh yang stabil dan perkembangan sesuai dengan milestone. ${ }^{9}$

\section{Pendekatan umum dan psikososial}

Kemampuan menerangkan diagnosis dan kondisi penyakit kepada pasien dan keluarganya merupakan hal yang penting. Abdominal migrain yang secara medis tidak bisa diterangkan atau disebut juga nyeri psikogenik dapat menimbulkan depresi dan kegelisahan pada anak dan orang tuanya. Model biopsikososial nyeri dan manajemen gejala menekankan pandangan holistik tentang kehidupan pasien. Terapi perilaku kognitif dapat memperbaiki nyeri pada nyeri abdomen fungsional tetapi tidak terdapat data spesifik mengenai abdominal migrain. Memahami dan menghindari faktor pencetus (seperti stres emosional, terlambat makan, dan kurang tidur) sangat membantu mengurangi gejala. Gejala akut membaik pada $>80 \%$ pasien yang beristirahat diruangan gelap dan sunyi dan pemberian analgetik sederhana seperti paracetamol $15 \mathrm{mg} / \mathrm{kg}$ atau ibuprofen $10 \mathrm{mg} / \mathrm{kg}$. Sumatriptan dengan dosis $10 \mathrm{mg}$ intranasal (triptan, agonis serotonin) direkomendasikan untuk pemakaian akut. $^{9,10}$

\section{Pendekatan farmakologi}

Penggunaan terapi farmakologi pada penderita abdominal migrain masih belum banyak diteliti. Pizotifen sampai saat ini merupakan terapi yang sering digunakan pada abdominal migrain. Pendapat ahli direkomendasikan untuk penggunaan obat-obatan lain karena sedikitnya data yang tersedia seperti cyproheptadine, propanolol, flunarazine, sodium valproate, dyhidroergotamine, amitriptyline, topiramate.

- Pizotifen (agonis serotonin) 0.25 mg, dua kali sehari dalam bentuk sirup

- $\quad$ Propanolol (beta bloker) $10-20 \mathrm{mg}$, dua atau tiga kali sehari

- Cyprohepatadine (antihistamin) 0.25-0.5 mg/kg sekali sehari, dalam bentuk sirup

- $\quad$ Flunarazine (Ca channel blocker) 5-7.5 mg/hari

- Sodium valproat (anti epilesi) 500 mg tiga kali sehari diberikan intravena 
- Dihydroergotamin (ergot) $0.5 \mathrm{mg}$ diberikan intravena, dapat ditingkatkan sampai 7-9 mg perhari $^{10}$

\section{Konstipasi $^{11}$}

Konstipasi fungsional merupakan masalah yang sering terjadi pada anak, dengan prevalensi sekitar 3\% di seluruh dunia. Sekitar 17\% sampai 40\% anak mengalami konstipasi pada tahun pertama kehidupan. Konstipasi berhubungan dengan jarangnya dan/atau defekasi yang nyeri, inkontinensia fekal dan nyeri abdomen, menyebabkan distress yang signifikan terhadap anak dan keluarga. Definisi konstipasi fungsional berdasarkan kriteria Rome III yang dibagi menjadi dua kelompok usia, bayi sampai usia 4 tahun harus memenuhi $\geq 2$ kriteria paling kurang selama 1 bulan, sedangkan $>4$ tahun harus memenuhi $\geq 2$ kriteria setidaknya selama 2 bulan.

\section{Balita dan anak ${ }^{11}$}

- Konstipasi Akut

Untuk anak usia $\geq 1$ tahun dengan feses yang keras tetapi tidak terdapat nyeri dan kebiasaan menahan feses, perdarahan atau fisura ani, modifikasi diet sudah mencukupi. Makanan yang dianjurkan adalah makanan tinggi serat ( $\geq 3$ gram), disertai dengan intake cairan yang adekuat (960 sampai 1920 ml per hari). Balita dan anak dengan kebiasaan menahan defekasi, nyeri saat $B A B$ dan perdarahan rectum atau fisura ani dianjurkan untuk diberikan terapi polyethylene glycol (PEG) $0.4 \mathrm{~g} / \mathrm{kg} / \mathrm{hari}$. Bila anak terdapat impaksi feses maka dibutuhkan dosis PEG yang lebih tinggi 1 sampai $1.5 \mathrm{~g} / \mathrm{kg} / \mathrm{hari}$ dapat diberikan maksimal selama 6 hari. Alternatif lain adalah lactulose yang aman untuk semua umur. Fisura ani dapat diterapi dengan memberikan minyak jelly, disamping itu diet tinggi serat juga harus diberikan untuk menghindari terjadinya konstipasi berulang.

- Konstipasi Berulang

Anak dan balita dengan konstipasi berulang sangat penting untuk mengenal masalah diet dan/atau peristiwa yang dapat mencetus terjadinya konstipasi seperti episode berulang defekasi yang nyeri (seperti fisura ani, feses yang keras), takut menggunakan toilet, terapi yang tidak adekuat dan pemberian laksatif dini, dan penggunaan kamar mandi yang tidak optimal setelah makan. Intervensi yang dapat dilakukan antara lain :

a. Optimalisasi diet tinggi serat - Pemantauan diet untuk memastikan diet serat adekuat, bila tidak maka dapat diberikan suplemen serat. Supaya lebih efektif ditambah dengan konsumsi air atau air non susu sebanyak 960-1920 ml perhari.

b. Laksatif

Laksatif pada saat onset suatu episode konstipasi berguna untuk membersihkan feses yang keras dan merangsang pergerakan usus. Dosis maintenance laksatif dipertimbangkan apabila feses tetap keras, diameter besar atau terus menyebabkan nyeri.

c. Disimpaksi

Anak dengan motilitas usus yang hilang selama beberapa hari dan tidak bisa mengeluarkan feses akan mengalami impaksi feses yang harus diberikan laksatif oral dosis tinggi selama 1 minggu, atau sodium fosfat enema diikuti dengan pemberian laksatif oral.

Bayi $^{12}$

Konstipasi yang terjadi pada bayi selepas masa neonatus pada umumnya disebabkan oleh perubahan diet seperti perubahan ke makanan padat.

- Konstipasi akut

Pada bayi yang belum mendapat makanan padat, konstipasi akut dapat diterapi dengan memberikan karbohidrat osmosis aktif yang tidak dicerna kedalam susu formula, dosis dinaikkan perlahan untuk merangsang motilitas usus. Misalnya dengan menambahkan jus yang mengandung sorbitol (seperti apel, buah prem, atau pir). Bayi berusia $\geq 4$ bulan, 2 sampai 4 ons jus buah 100\% perhari dapat diberikan sebagai dosis permulaan. Bayi kurang dari 4 bulan, 1-2 ons jus prem yang dicairkan dapat diberikan sebagai dosis permulaan. Bayi yang sudah mendapatkan makanan padat dapat diberikan diet sorbitol mengandung puree buahbuahan. Gliserin supposituria atau stimulasi rektal dengan menggunakan thermometer yang sudah diberi pelumas dapat digunakan bila terdapat feses yang keras pada rektum. Hati-hati penggunaan 
gliserin karena bisa menyebabkan iritasi mukosa rectum dan anus.

- Konstipasi berulang

Bayi dengan konstipasi berulang tetap ditatalaksana dengan intervensi diet tinggi serat seperti pada konstipasi akut. Penggunaan gliserin atau stimulasi rektal dengan menggunakan termometer yang sudah diberi pelumas untuk membersihkan feses yang keras, tetapi penggunaannya tidak boleh terus menerus karena akan menyebabkan ketergantungan. Bayi $>6$ tahun selain intervensi diet, terapi dapat ditambah dengan memberikan laksatif osmotik seperti PEG, laktulosa atau sorbitol yang diberikan setiap hari untuk mendapatkan feses yang lunak. Penggunaan laksatif stimulan (senna dan bisacodyl), minyak mineral dan enema harus dihindari karena efek sampingnya.

\section{Functional Abdominal Pain Disorder (FAPDs)}

Istilah kronik sering digunakan dalam mendeskripsikan FAPDs, tetapi setiap episode nyeri berbeda dan dipisahkan oleh periode sehat. Gejala yang paling sering adalah nyeri pada periumbilikal yang berhubungan dengan gejala otonom dan fungsional seperti mual, muntah, pucat dan gejala nyeri lainnya seperti sakit kepala dan nyeri pada tungkai. FAPDs pada awalnya menyerupai gejala akut abdomen lainnya sehingga menyebabkan pemeriksaan yang sebenarnya tidak diperlukan. Sering didapatkan riwayat keluarga dengan FAPDs (keluarga tingkat pertama), yang mungkin disebabkan oleh genetik atau kerentanan lingkungan. $^{13}$

\section{Tatalaksana Umum ${ }^{14}$}

a. Therapeutic relationship

Suatu hubungan antara dokter-pasien/keluarga penting dalam tatalaksana FAPDs. Pasien atau keluarga harus percaya bahwa keluhan dan kekahwatiran mereka didengarkan dengan baik. Pengertian keluarga menerima bahwa nyeri tipe biopsikososial merupakan faktor penting dalam penyembuhan anak.

b. Edukasi pasien

- FAPDs merupakan penyakit yang sering terjadi mengenai hampir $10-20 \%$ anak.

- $\quad$ Nyeri pada FAPDs bersifat nyata
- Nyeri pada FAPDs dapat dicetus, eksaserbasi, atau bertahan oleh karena pengaruh lingkungan dan faktor psikososial seperti stress, gelisah, dan masalah sosial (perhatian, perarturan ketat).

- Nyeri tidak bersifat mengancam hidup dan tidak memerlukan pembatasan aktivitas

- Tatalaksana terutama bertujuan untuk mengembalikan aktifitas normal

- Tatalaksana nyeri meliputi menghindari factor pencetus dan meningkatkan kemampuan, nyeri mungkin akan tetap ada tetapi kualitas hidup anak dan keluarga dapat ditingkatkan.

- Harus mempunyai tujuan tatalaksana yang jelas seperti mempertahankan aktifitas normal dan meningkatkan toleransi terhadap gejala.

- Nyeri kronik tanpa memandang penyebabnya dapat menimbulkan depresi atau kegelisahan (keduanya dapat menjadi penyebab atau sebagai akibat).

c. Melanjutkan pendidikan

Absen dari sekolah akibat nyeri akan menambah stress pada keluarga dan mempengaruhi kemampuan anak dan fungsi sosialnya. Fasilitasi yang dapat diberikan adalah sebagai berikut :

- Memberikan solusi bila nyeri muncul saat sekolah seperti segera pergi ke fasilitas kesehatan sekolah

- Memberikan bekal kepada orang tua kapan memutuskan bahwa anak terlalu sakit untuk pergi ke sekolah, atau harus segera dipulangkan dari sekolah. Tetapi bila anak terlalu sering dipulangkan dari sekolah justru akan menambah gejala.

- Membekali dengan panduan pembatasan aktivitas bila anak tinggal dirumah

- Mengidentifikasi dan mengenal stress akibat sekolah (misalnya bulliying, isolasi sosial dan penempatan kelas yang tidak sesuai, dll)

- Memberitahu pihak sekolah bahwa anak membutuhkan penggunaan toilet yang lebih sering

- Memberitahu sekolah bahwa anak memerlukan izin untuk menjalani pemeriksaan yang berkenaan dengan penyakitnya 
d. Modifikasi perilaku

- Memberikan pujian atau hadiah bila anak menghadiri sekolah atau mengikuti kegiatan ekstrakurikuler di sekolah

- Mengenal dan memberikan dukungan terhadap minat dan bakat anak

- Pola pengasuhan respon terhadap nyeri abdomen

e. Memperbaiki coping

Coping adalah usaha sukarela untuk mengelola emosi, pikiran, sikap, fisiologis dan lingkungan dalam memberikan respon terhadap kejadian berat/menyebabkan stress.

- Teknik relaksasi

Anak besar dan remaja dapat diajari untuk melakukan teknik relaksasi singkat seperti mengambil nafas dalam sedikitnya dua kali dalam sehari. Tujuannya adalah membantu anak untuk merasa rileks saat dalam kesakitan.

Terapi relaksasi ini dapat membantu mengurangi rasa nyeri dan memperbaiki fungsional anak.

- Pengalihan

Pengalihan dari rasa sakit, dapat berupa ngobrol, permainan, televisi dan hipnoterapi.

- Hipnoterapi

Merupakan teknik pengalihan sehingga anak dapat relaks dan mengalihkan anak dari rasa sakit. Hipnoterapi dapat menyertakan gambar yang dibayangkan, suara, atau sensasi untuk menghasilkan keadaan penerimaan, juga dikenal sebagai hipnoterapi "gut-directed" yang dapat dilakukan sendiri atau dengan panduan terapis.

- Terapi perilaku kognitif

Pendekatan psikoterapi yang mengidentifikasi hubungan antara perilaku, pikiran, dan perasaan untuk mempengaruhi perubahan terapi meliputi berbagai kombinasi dari pendidikan, relaksasi, manajemen stress, dan modifikasi perilaku. Metaanalisis tahun 2017 mendapatkan terapi perilaku kognitif ini cukup berhasil dalam mengatasi FAPDs tetapi tidak untuk jangka waktu yang lama.
- Terapi lainnya

Biofeedback, yoga juga digunakan untuk mengurangi gejala, tetapi tidak banyak membantu.

Tatalaksana terhadap pencetus

a. Makanan pencetus

- Laktosa

Diet bebas laktosa bermamfaat bila gejala dipengaruhi oleh intoleransi laktosa. Diet dengan membatasi konsumsi susu dan produk susu. Bila dengan diet gejala tidak membaik dalam 2 minggu maka konsumsi laktosa dapat kembali diberikan.

- Gluten/gandum

Diet bebas gluten mulai dikemukakan setelah diketahui bahwa gluten berhubungan dengan sensitivitas atau celiac disease pada nyeri abdomen kronik.

- FODMAPs

Merupakan kelompok karbohidrat yang dievaluasi sebagai penyebab FGIDs (functional gastrointestinal disorders), merupakan makanan yang mengandung karbohidrat rantai pendek yang tidak diserap dengan baik oleh saluran cerna sehingga menyebabkan produksi gas, distensi usus besar, kembung dan nyeri perut.

b. Kecemasan

Mengidentifikasi adanya kecemasan pada pasien FAPDs sangat penting karena mempengaruhi sebanyak $42-85 \%$. Merujuk ke psikiater merupakan cara mengatasi adanya kecemasan pada anak.

Tatalaksana Mengatasi Gejala ${ }^{15,16}$

a. Nyeri abdomen

- Probiotik

Probiotik memperbaiki gejala dengan mengembalikan keseimbangan microbiota usus melalui kompetisi metabolik dengan patogen, memperbaiki barrier mukosa usus, atau meningkatkan respon inflamasi usus. Gunakan probiotik yang telah memiliki bukti benefit seperti Lactobacillus rhamnosus, Lactobacillus reuteri, digunakan selama 4 sampai 6 minggu kemudian lakukan penilaian kembali gejala. 
- Serat

Serat dapat memodifikasi mikrobiota usus, meningkatkan komposisi feses dan gas, dan/atau mempercepat transit saluran cerna. Dosis optimal, jenis serat dan lama terapi baku masih belum ada. Dianjurkan untuk menggunakan serat larut air seperti psyllium hydrophilic mucilloid (spaghula husk) dosis 1.5 sampai 12.5 gram per hari. Target konsumsi serat pada anak adalah usia (dalam tahun) ditambah 5 sampai 10 gram perhari. Suplementasi serat ini diberikan selama 4 minggu sebelum dilakukan lagi penilaian apakah terapi ini berhasil atau tidak.

- Minyak peppermint/antispasmodik

Minyak peppermint mengurangi spasme otot polos pada saluran cerna sehingga mengurangi lama nyeri, frekuensi dan beratnya nyeri. Minyak peppermint berupa ph-dependent enteric coated capsule (187 mg tiga kali sehari untuk anak $\mathrm{BB}<45 \mathrm{~kg} ; 374 \mathrm{mg}$ tiga kali sehari untuk anak BB $>45 \mathrm{~kg}$ ). Sementara itu penggunaan antispasmodik pada anak masih membutuhkan penelitian lebih lanjut pada anakanak.

- Intervensi lain

Pemberian antidepresan (amitriptilin, citalopram) direkomendasikan apabila disertai dengan depresi sesuai dengan kriteria DSM 5. Cyproheptadine merupakan obat dengan fungsi antihistamin, antikolinergik, dan antiserotonergik dan mempunyai efek $\mathrm{Ca}$ channel blocker digunakan untuk menambah nafsu makan dan mencegah nyeri dan muntah pada abdominal migraine serta sindrom muntah siklik.

b. Dispepsia

Dispepsia dapat diatasi dengan cara small frequent meal dan menghindari makanan dan obat-obatan yang dapat meningkatkan gejala. Terapi farmakologi yang digunakan adalah $\mathrm{H} 2$ blocker (simetidin, ranitidine, nizatidin, atau famotidine), proton pump inhibitor (lansoprazol, esomeprazole) selama 4-6 minggu, dan dihentikan bila tidak terdapat kemajuan. c. Diare

Diare bisa berhubungan dengan beberapa makanan pencetus seperti laktosa, sorbitol sehingga harus dilakukan retriksi terhadap makanan yang mengandung kedua bahan tersebut. Penggunaan antimotilitas tidak direkomendasikan karena diare biasanya hanya berlangsung singkat.

d. Konstipasi

Identifikasi penyebab konstipasi.

\section{Perdarahan Saluran Cerna}

\section{Perdarahan Saluran Cerna Atas ${ }^{17,18}$}

Pasien yang secara hemodinamik stabil dengan jumlah perdarahan yang sedikit dan penyebab yang jelas terapi suportif dengan pemantauan keadaan umum dan diberikan penekan asam lambung untuk mengurangi risiko perdarahan ulang. Pasien dengan hemodinamik yang tidak stabil dan jumlah perdarahan yang banyak maka tatalaksananya adalah sebagai berikut:

a. Pipa nasogastrik

Pasien dengan perdarahan saluran cerna yang tidak diketahui sebabnya dan jumlah perdarahan yang signifikan, penggunaan pipa nasogastrik/orogastrik dapat membantu menegakkan diagnosis dan menentukan perdarahan sedang berlangsung atau tidak. Bilas lambung membantu membuang benda asing, darah segar dan bekuan sehingga memudahkan untuk melakukan endoskopi dan mengurangi risiko aspirasi. Bilas lambung dapat dilakukan dengan menggunakan normal salin atau aquades.

b. Terapi farmakologik

- Acid suppression

Dapat diberikan proton pump inhibitor (esomeprazole atau pantoprazole) atau antagonis reseptor histamine 2/H2RA (ranitidine, famotidine atau simetidin) yang diberikan secara intravena.

- Somatostatin dan octreotide

Octreotide (analog somatostatin) dapat membantu mengurangi perdarahan saluran cerna yang sulit dikontrol, dan sebagai terapi adjuvant untuk membantu mengontrol perdarahan sebelum dilakukan endoskopi, atau bila endoskopi tidak berhasil, kontraindikasi atau tidak tersedia. Octreotide mengurangi 
inflow vena porta dan tekanan intravarises sehinggan mengurangi risiko perdarahan ulang akibat perdarahan varises atau penyebab non varises. Octreotide diberikan sebagai bolus awal 1-2 mikrogram/kg (maksimal 100 mikrogram) dilanjutkan dengan 1-2 mikrogram $/ \mathrm{kg} / \mathrm{jam}$ sebagai infus kontinu, kecepatan infus dapat dititrasi sesuai respon yang terjadi. Efek samping berupa bradikardi dan hiperglikemi. Bila perdarahan berhenti dosis octreotide dapat diturunkan secara bertahap dalam waktu 24 jam. Penggunaan octreotide pada anak masih terbatas sehingga beberapa lebih memilih menggunakan vassopresin karena lebih efektif dan efek samping yang sedikit.

Tabel 1. Pilihan farmakologi untuk anak dengan perdarahan gastrointestinal ${ }^{18}$

\begin{tabular}{|c|c|c|}
\hline & Dosis & Kategori \\
\hline \multicolumn{3}{|c|}{ Acid suppression (IV) } \\
\hline Esomeprazole & $\begin{array}{l}\text { Dosis intermiten : } \\
\text { Bayi : } 0.5-1 \mathrm{mg} / \mathrm{kg} / \text { dosis IV } 1 \mathrm{x} / \text { hari } \\
\text { Anak } 1-17 \text { tahun : } \\
<55 \mathrm{~kg}: 10 \mathrm{mg} \text { IV } 1 \mathrm{x} \text { atau } 2 \mathrm{x} / \text { hari } \\
>55 \mathrm{~kg}: 20 \mathrm{mg} \text { IV } 1 \mathrm{x} \text { atau } 2 \mathrm{x} / \text { hari } \\
\text { Infus kontinu : } 1 \mathrm{mg} / \mathrm{kg} \text { bolus IV (maksimal } 80 \mathrm{mg} \text { ), diikuti } 0.1 \mathrm{mg} / \mathrm{kg} / \mathrm{jam} \text { (maksimal } 8 \\
\mathrm{mg} / \mathrm{jam})\end{array}$ & PPI \\
\hline Omeprazole & $\begin{array}{l}\text { Anak dan remaja : } 0.5-3 \mathrm{mg} / \mathrm{kg} \text { IV setiap hari dalam satu atau dua dosis terbagi } \\
\text { (maksimal } 80 \mathrm{mg} \text { perhari) }\end{array}$ & PPI \\
\hline Pantoprazole & $\begin{array}{l}\text { Dosis intermiten : } \\
\text { Anak dan remaja : } \\
<40 \mathrm{~kg}: 0.5-1 \mathrm{mg} / \mathrm{kg} \mathrm{IV} 1 \mathrm{x} \text { atau } 2 \mathrm{x} / \mathrm{hari} \\
>40 \mathrm{~kg}: 20-40 \mathrm{mg} \text { IV } 1 \mathrm{x} \text { atau } 2 \mathrm{x} / \mathrm{hari} \\
\text { Infus kontinu : } 1 \mathrm{mg} / \mathrm{kg} \text { bolus (maksimal } 80 \mathrm{mg} \text { ) diikuti } 0.1 \mathrm{mg} / \mathrm{kg} / \mathrm{jam} \text { (maksimal } 8 \\
\mathrm{mg} / \mathrm{jam} \text { ) }\end{array}$ & PPI \\
\hline Ranitidine & $\begin{array}{l}\text { Dosis intermiten: } \\
\text { bayi, anak dan remaja : } 2-5 \mathrm{mg} / \mathrm{kg} / \mathrm{hari} \text { IV dibagi setiap } 6-8 \text { jam dengan dosis } \\
\text { maksimal } 200 \mathrm{mg} / \mathrm{hari} \\
\text { Infus kontinu : anak dan dewasa : } 1 \mathrm{mg} / \mathrm{kg} \text { bolus IV (maksimm } 50 \mathrm{mg} \text { ) diikuti } 2-4 \\
\mathrm{mg} / \mathrm{kg} / \text { hari (maksimum } 6.25 \mathrm{mg} / \mathrm{jam} \text { ) }\end{array}$ & PPI \\
\hline Acid suppressio & & \\
\hline Omeprazole & $\begin{array}{l}\text { Anak dan remaja : } 1-3 \mathrm{mg} / \mathrm{kg} \text { per hari, (maksimal } 80 \mathrm{mg} \text { perhari), dibagi menjadi } 1 \text { atau } \\
\text { dua dosis perhari }\end{array}$ & PPI \\
\hline Esomeprazole & $\begin{array}{l}\text { Bayi (1 bulan-1 tahun) dosis perhari : } \\
3-5 \mathrm{~kg}: 2.5 \mathrm{mg} \\
5-7.5 \mathrm{~kg}: 5 \mathrm{mg} \\
7.5-12 \mathrm{~kg}: 10 \mathrm{mg} \\
\text { Anak usia } 1-11 \text { tahun dosis perhari : } \\
\text { BB <20 } \mathrm{kg}: 10 \mathrm{mg} \\
\text { BB >20 } \mathrm{kg}: 10 \mathrm{mg} \text { atau } 20 \mathrm{mg} \\
\text { Anak } \geq 12 \text { tahun dan dewasa : } 40 \mathrm{mg} \text { dua kali sehari, diikuti } 20-40 \mathrm{mg} \text { sekali sehari }\end{array}$ & PPI \\
\hline Pantoprazole & $\begin{array}{l}\text { Anak 5-11 tahun: } \\
\text { BB } 15-40 \mathrm{~kg}: 20 \mathrm{mg} \text { sekali sehari } \\
\mathrm{BB}>40 \mathrm{~kg}: \text { gunakan dosis dewasa } \\
\text { Anak } \geq 12 \text { tahun dan dewasa : } 40 \mathrm{mg} \text { dua kali sehari, diikuti } 20-40 \mathrm{mg} \text { sekali sehari }\end{array}$ & PPI \\
\hline $\begin{array}{l}\text { Agen vasoaktif } \\
\text { Octreotide }\end{array}$ & $\begin{array}{l}\text { Anak : } 1-2 \mathrm{mcgram} / \mathrm{kg} \text { IV bolus (maksimal } 50 \mathrm{mcgram} \text { ) diikuti } 1-2 \mathrm{mcgram} / \mathrm{kg} / \mathrm{jam} \\
\text { sebagai infus kontinu (maksimal } 50 \mathrm{mcgram} \text { per jam). Dosis inisial dapat diulangi } 1 \mathrm{x} \\
\text { dalam jam pertama bila dibutuhkan. }\end{array}$ & $\begin{array}{l}\text { Analog } \\
\text { somatostatin }\end{array}$ \\
\hline
\end{tabular}




\section{c. Endoskopi}

Protokol merekomendasikan endoskopi dilakukan dalam waktu 24-48 jam pada bayi dan anak dengan perdarahan saluran cerna atas yang bersifat akut dan berat. Pasien dengan hemodinamik tidak stabil harus distabilkan terlebih dahulu dengan memberikan transfuse dan koreksi koagulopati. Endoskopi membantu identifikasi sumber perdarahan, memungkinkan untuk stratifikasi risiko mengenai kemungkinan pendarahan lanjutan, dan memungkinkan intervensi terapeutik. Terdapat beberapa pertimbangan tindakan endoskopi pada anak, yaitu:

- Anak membtuhkan sedasi dalam atau anestesi umum untuk tindakan endoskopi. Untuk pasien dengan peradrahan aktif atau berat, atau terapi endoskopi dibutuhkan maka dibutuhkan anestesi umum dengan intubasi endotrakeal, disamping komplikasi lebih sedikit dibandingkan obat sedasi.

- Endoskopi kaliber kecil membatasi kateter yang dapat melewati saluran.

Endoskopi secara umum sukses mengatasi perdarahan aktif. Pembedahan atau angiografi direncanakan untuk pasien bila endoskopi gagal dalam mengontrol perdarahan atau pada anak dengan kelainan anatomi yang membutuhkan tindakan bedah, atau pada pasien yang dapat stabil sepenuhnya. ${ }^{19,20}$

\section{Perdarahan Saluran Cerna Bawah}

a. Terapi injeksi

\section{- Epinefrin}

Epinefrin mmempunyai beberapa mekanisme aksi, termasuk vasokontriksi dan agregasi trombosit. Kosentrasi epinefrin efektif dan aman adalah 1:10 000 untuk perdarahan lambung dan saluran cerna dengan pengenceran $1 \mathrm{cc}$ epinefrin $1 ; 1000+9 \mathrm{cc} \mathrm{NaCl} 0.9 \%$. Biasanya digunakan dosis 0.5-2 cc per injeksi, dilakukan injeksi 4 kuadran 2-3 $\mathrm{mm}$ dari perdarahan, dengan maksimal volume injeksi $10 \mathrm{cc} .^{21}$

- Ethanol

Ethanol memberikan efek hemostasis melalui efek dehidrasi pada mukosa, tetapi penggunaan ethanol pad anak masih diteliti. ${ }^{21}$ b. Perangkat termal

Energi termal menyebabkan edem jaringan, koagulasi, dan kontraksi pembuluh darah. Koaptasi koagulasi digunakan dengan probe kontak, dan mengacu pada gabungan mekanisme tamponade tekanan langsung oleh probe ke pembuluh darah diikuti oleh pengiriman energi panas untuk merusak dinding pembuluh. Penggunaan perangkat monopolar, seperti hot biopsy forceps, tidak disukai, karena kedalaman energi panas kurang terkontrol. Kebanyakan endoscopists lebih memilih probe bipolar dan pemanas (HP), mengingat kemudahan penggunaan, ketersediaan, dan keamanan, termasuk kurangnya kebutuhan pad landasan karena seluruh sirkuit ditutup ujung perangkat. Dalam praktek klinis, banyak endoskopi pediatrik lebih memilih bipolar probe dibandingkan dengan HP karena pengalaman klinis yang lebih luas. $^{22}$

c. Clips

Clips menyebabkan tamponade mekanik tanpa menimbulkan kerusakan jaringan. Beberapa klip bisa ditempatkan secara berurutan untuk memberikan tamponade dikedua sisi pembuluh darah setelah lebih dulu mengamankan titik langsung pendarahan. Nomenklatur dalam literatur untuk aksesori ini termasuk klip endoclip, hemoclip, dan through-the-scope (TTS). ${ }^{23}$

d. Terapi lain Hemospray merupakan serbuk yang diberikan melalui kateter TTS dan system pressurized $\mathrm{CO}_{2}$. Serbuk akan diserap dan mengkosentrasikan factor pembekuan, membentuk sumbatan mekanik pada vena yang berdarah. Tetapi penggunaannya belum diteliti lanjut pada anak. ${ }^{24}$ Klip over-thescope (OTSC) (Ovesco Endoscopy AG, Tubingen, Jerman) adalah klip dimuat ke endoskopi dengan rahang terbuka. Dibandingkan dengan klip TTS, OTSC memiliki kekuatan kompresi dan kapasitas yang lebih tinggi untuk menangkap volume jaringan yang lebih besar efektif untuk kedua hemostasis dan penutupan perforasi. ${ }^{25}$ 


\section{SIMPULAN}

Pendekatan berbagai multidimensi diperlukan mulai dari perubahan gaya hidup, pendekatan umum psikososial, terapi suportif serta tatalaksana mendikamentosa pada pasien dengan GERD, abdominal migraine, konstipasi, FAPDs serta perdarahan saluran cerna.

\section{DAFTAR PUSTAKA}

1. Lightdale JR, Gremse DA. Section on gastroenterology, hepatology, and nutrition. gastroesophageal reflux: management guidance for the pediatrician. Pediatrics. 2013;131:1684-95.

2. Headache Classification Subcommittee of the International Headache Society. The international classification of headache disorders: 2nd edition. Cephalalgia. 2004;24(Suppl1):9-160.

3. Loening-Baucke V. Prevalence, symptoms and outcome of constipation in infants and toddlers. J Pediatr. 2005;146:359-63.

4. Di Lorenzo C, Youssef NN, Sigurdsson L, Scharff L, Griffiths J, Wald A. Visceral hyperalgesia in children with functional abdominal pain. J Pediatr. 2001; 139: 838-43.

5. Pillai RB, Tolia V. Gastrointestinal bleeding in infants and children. Therapy. 2008;4:465-73.

6. Heacock HJ, Jeffery HE, Baker JL, Page $M$. Influence of breast versus formula milk on physiological gastroesophageal reflux in healthy, newborn infants. J Pediatr Gastroenterol Nutr. 1992; 14:41-6.

7. Kwok TC, Ojha S, Dorling J. Feed thickener for infants up to six months of age with gastrooesophageal reflux. Cochrane Database Syst Rev. 2017;12:1-73.

8. Task Force on Sudden Infant Death Syndrome, Moon RY. SIDS and other sleep-related infant deaths: expansion of recommendations for a safe infant sleeping environment. Pediatrics. 2011;128:136.

9. Vandenplas $\mathrm{Y}$, Rudolph CD, di Lorenzo C, Hassall E, Liptak G, Mazur L, et al. Pediatric gastro esophageal reflux clinical practice guidelines: Joint recommendations of the North American Society for Pediatric Gastroenterology, Hepatology and Nutrition (NASPGHAN) and the European Society for Pediatric Gastroenterology, Hepatology, and Nutrition (ESPGHAN). J. Pediatr. Gastroenterol. Nutr. 2009;49:498-547.

10. Drossman DA. Functional gastrointestinal disorders: history, pathophysiology, clinical features and Rome IV. Gastroenterology. 2016:150:1262-79.

11. Tabbers MM, DiLorenzo C, Berger MY, Faure C, Langendam MW, Nurko S, et al. Evaluation and treatment of functional constipation in infants and children: evidence-based recommendations from ESPGHAN and NASPGHAN. J Pediatr Gastroenterol Nutr. 2014;58:258-74.

12. Abi-Hanna A, Lake AM. Constipation and encopresis in childhood. Pediatr Rev. 1998;19:2331.

13. Belamarich, PF. Constipation. In: Primary Pediatric Care, 4th ed, Hoekelman, RA (Ed), Mosby, St. Louis. 2001.hlm.1066.

14. Boey CC, Goh KL. Predictors of recurrent abdominal pain among 9 to 15-year-old urban school-children in Malaysia. Acta Paediatr. 2001;90: 353-5.

15. Rutten JMTM, Vlieger AM, Frankenhuis C, George EK, Groeneweg M, Norbruis OF, Ten WT, et al. Home-based hypnotherapy self-exercises vs individual hypnotherapy with a therapist for treatment of pediatric irritable bowel syndrome, functional abdominal pain, or functional abdominal pain syndrome: a randomized clinical trial. JAMA Pediatr. 2017;171:1-7.

16. Newlove-Delgado TV, Martin AE, Abbott RA, Bethel A, Thompson-Coon J, Whear $\mathrm{R}$, et al. Dietary interventions for recurrent abdominal pain in childhood. Cochrane Database Syst Rev. 2017;3:187.

17. Pinto-Sanchez MI, Yuan Y, Bercik P, Moayyedi P. Proton pump inhibitors for functional dyspepsia. Cochrane Database Syst Rev.2017;3:1-97.

18. Imperiale TF, Birgisson S. Somatostatin or octreotide compared with $\mathrm{H} 2$ antagonists and placebo in the management of acute nonvariceal upper gastrointestinal hemorrhage: a meta-analysis. Ann Intern Med.1997;127:1062-71.

19. Balsells F, Wyllie R, Kay M, Steffen R. Use of conscious sedation for lower and upper gastrointestinal endoscopic examinations in 
children, adolescents, and young adults: a twelveyear review. Gastrointest Endosc.1997;45:375-80.

20. Prabhu NC, Song LM. Achieving hemostasis and the risks associated with therapy. Gastrointest Endosc Clin N Am. 2015;25:123-45.

21. Park WG, Yeh RW, Triadafilopoulos G. Injection therapies for nonvariceal bleeding disorders of the GI tract. Gastrointest Endosc. 2007;66:343-54.

22. Harrison JD, Morris DL. Does bipolar electrocoagulation time affect vessel weld strength?. Gut. 1991;32:188-90.
23. Kay MH, Wyllie R. Therapeutic endoscopy for nonvariceal gastrointestinal bleeding. J Pediatr Gastroenterol Nutr. 2007;45:157-71.

24. Tjwa ET, Holster IL, Kuipers EJ. Endoscopic management of nonvariceal, nonulcer upper gastrointestinal bleeding. Gastroenterol Clin North Am. 2014;43:707-19.

25. Wright R, Abrajano C, Koppolu R, Stevens M, Nyznyk S, Chao S, et al. Initial results of endoscopic gastrocutaneous fistula closure in children using an over-the-scope clip. J Laparoendosc Adv Surg Tech A. 2015;25:69-72. 